\title{
Pre- and postsynaptic M3 muscarinic receptor mRNAs in the rodent peripheral auditory system
}

\author{
Saaid Safieddine ${ }^{\mathrm{a}, \mathrm{c}}$, Sylvain Bartolami ${ }^{\mathrm{b}}$, Robert J. Wenthold ${ }^{\mathrm{c}}$, Michel Eybalin ${ }^{\mathrm{a}, *}$ \\ a INSERM U.254 and Université de Montpellier I, Laboratoire de Neurobiologie de l'Audition. CHU Hôpital Saint Charles, 34295 Montpellier cedex 5 , \\ France \\ ${ }^{\mathrm{b}}$ INSERM U.432 and Université de Montpellier II, 34095 Montpellier cedex 5, France \\ ${ }^{c}$ Laboratory of Neurochemistry, National Institute on Deafness and Other Communication Disorders, National Institutes of Health, Building 36, Room \\ 5D08, Bethesda, MD 20892, USA
}

Accepted 23 January 1996

\begin{abstract}
The medial and lateral efferent innervations originate from distinct parts of the superior olivary complex. Both use acetylcholine, respectively, to modulate the activity of outer hair cells ( $\mathrm{OHC}$ ), and spiral ganglion neurons (SGN) which are postsynaptic to the inner hair cells (IHC). Besides predominantly activating nicotinic receptors, acetylcholine recognizes muscarinic M3 receptors, whose the role(s) and cellular localization(s) are not yet firmly established. We used reverse transcription and polymerase chain reaction to amplify the M3 receptor cDNA in the rat and guinea pig organ of Corti and spiral ganglion. Then, we localized the M3 receptor mRNAs in cochleas and superior olivary complex of both species. The M3 receptor cDNA was amplified from samples of brain, organ of Corti and spiral ganglion. Indeed, its corresponding mRNA was localized in SGNs, OHCs and IHCs. However, in the apical turns, OHCs were often found unlabeled. In the superior olivary complex, M3 mRNAs were colocalized with choline acetyltransferase mRNAs in neurons of the lateral superior olive and ventral nucleus of the trapezoid body. These results suggest that the M3 receptor-induced inositol phosphate formation described in previous studies [21] takes place in both postsynaptic (SGNs, OHCs) and presynaptic components of efferent cochlear synapses, and in cells that are not contacted by efferents in the adult cochlea (IHCs).
\end{abstract}

Keywords: Acetylcholine; Efferent innervation; Cochlea; Superior olivary complex; Guinea pig; Rat; Hybridization, in-situ; Reverse transcriptase-polymerase chain reaction

\section{Introduction}

The neurosensory epithelium of the cochlea, the organ of Corti, is innervated by afferent and efferent nerve fibers (see [47] for a review). The sensory inner (IHC) and outer (OHC) hair cells are presynaptic to the dendrites of type I and type II primary auditory neurons (afferent neurons), respectively. These neurons are located in the spiral ganglion and their axonal process projects to the cochlear nucleus. Two populations of brainstem neurons (efferent neurons) innervate the organ of Corti. They belong to either the lateral or the medial efferent systems according to their locations in the superior olivary complex and their sites of cochlear terminations. In rodents, lateral efferent neurons lie in the lateral superior olive (LSO), a nucleus

\footnotetext{
" Corresponding author. Fax: (33) 6752-5601; E-mail: eybalin@ citi2.fr
}

located laterally in the superior olivary complex, and project to the IHC region where they make axodendritic synapses with terminals of the type I afferent neurons in the so-called inner spiral bundle. Medial efferent neurons are located in medial subnuclei of the superior olivary complex, mainly the ventral nucleus of the trapezoid body (VNTB). Their axonic terminals directly synapse with the OHCs.

A great amount of data indicates that acetylcholine is a major neurotransmitter for both efferent innervations and that it acts predominantly via nicotinic receptors (see [17] for a review). Conversely, little is known about the role played by muscarinic receptors in the cochlea. Available data indicate a link with the polyphosphoinositide signalling pathway $[2,21,31,32]$ which may occur via an activation of $\mathrm{M} 3$ receptors as it is suggested by pharmacological studies on the inositol phosphate (IP) synthesis [21] and binding of $\left[{ }^{3} \mathrm{H}\right]$ quinuclidinyl benzilate [3]. This is in 
agreement with polymerase chain reaction $(\mathrm{PCR})$ data in the mouse cochlea [12] showing an expression of $\mathrm{M} 3$ transcripts (which correspond to the pharmacologically defined $\mathrm{M} 3$ receptor $[7,22]$ ). In addition, $m 1$ and $m 5$ genes coding IP-linked muscarinic receptors have also been reported [12].

The location of muscarinic receptors is still obscure. Conflicting data exist about an expression of muscarinic receptors by OHCs. It has been reported that isolated

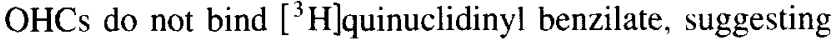
that they lack muscarinic receptors [33], but that they have a $\mathrm{Ca}^{2+}$-dependent potassium conductance activated via muscarinic receptors presumably coupled to the IP metabolism [26]. M3 receptors may also be located elsewhere in the cochlea. Accordingly, the IP synthesis can be stimulated by the activation of muscarinic receptors in both the organ of Corti and the modiolus, a region which contains the spiral ganglion, formed by primary auditory neurons surrounded by a glial sheath, and the auditory nerve [4]. Indeed, the acetylcholine-stimulated IP synthesis may thus be related to the previously described

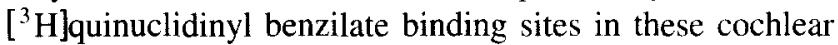
regions $[25,48]$.

In order to gain more insight into the anatomical localization of M3 receptors and into their putative role(s), we have used reverse transcriptase-polymerase chain reaction (RT-PCR) and in-situ hybridization (ISH) to detect mRNAs encoding M3 receptors in the rat and guinea pig spiral ganglions and guinea pig organs of Corti. In order to verify a possible expression of presynaptic M3 receptors on efferent terminals, we have also used ISH to localize at the cellular level M3 receptor transcripts in the superior olivary complex from both species. In this case, we compared on serial sections the distribution of mRNAs encoding M3 receptors and choline acetyltransferase (ChAT). This enzyme was used as a marker for efferent neurons since all the LSO neurons and large VNTB neurons projecting to the cochlea have previously been shown to be immunoreactive to ChAT $[1,46]$. This hypothesis that M3 muscarinic receptors are expressed on efferent terminals was based on the report of a decrease in carbachol-induced IP formation after a section of the contralateral component of the medial efferent innervation at the floor of the IVth ventricle [4]. It was also based on the absence of a cholinergic projection to the superior olivary complex (see [23]). A preliminary account of these results has been given [39].

\section{Material and methods}

\subsection{Reverse transcriptase-polymerase chain reaction}

The pair of primers used was designed using the DNASTAR program. The forward primer was 5'-GCTGCCTCCCTGGAAAACTCTGC-3', at position 1776-1798 of the rat M3 sequence (Genbank database accession no. M16407 [6]). The reverse primer was 5'-GGGCGGCCTTCTTCTCCTTGAT-3', at position 2220-2199. The predicted product length was $445 \mathrm{bp}$.

The temporal bones of 15 rats and 15 guinea pigs were removed, and the cochleas dissected. They were further microdissected to isolate the spiral ganglion and the organ of Corti. The RNA was extracted with guanidinium thiocyanate (GIBCO-BRL, Gaithersburg, MD) according to the manufacturer's instruction. The samples were treated with RNase-free DNase (Gen-Hunter Corp., MA) for 30 min at $37^{\circ} \mathrm{C}$ to remove residual contaminating DNA. One microgram of total RNA from the spiral ganglion and all the RNA prepared from the 30 organs of Corti $(<1 \mu \mathrm{g})$ were reverse-transcribed into cDNA. The reaction was catalysed by Superscript II reverse transcriptase lacking RNase $\mathrm{H}$ activity (GIBCO-BRL) using a random hexamer primer. The RNA and the hexamer random primer were combined in a thin-walled PCR tube (Perkin Elmer/Cetus, Norwalk, CT) and the volume was brought to $11.5 \mu \mathrm{l}$ with DEPC-treated water. The sample was heated to $70^{\circ} \mathrm{C}$ for $10 \mathrm{~min}$ in a model 9600 thermocycler (Perkin Elmer/Cetus) and then chilled on ice for $2 \mathrm{~min}$. The following solutions were then added: $2 \mu \mathrm{l}$ of $200 \mathrm{mM}$ Tris-HCl, $\mathrm{pH} 8.4,1 \mu \mathrm{l}$ of $500 \mathrm{mM} \mathrm{KCl}, 2 \mu \mathrm{l}$ of $\mathrm{MgCl}_{2}, 1$ $\mu 1$ of $0.1 \mathrm{M}$ dithiothreitol, $0.5 \mu \mathrm{l}$ of RNasin (Promega, Madison, WI) and $1 \mu \mathrm{l}$ of $10 \mathrm{mM}$ dNTP mix; the final volume was $19 \mu \mathrm{l}$. The samples were allowed to equilibrate at $37^{\circ} \mathrm{C}$ for $5 \mathrm{~min}$. One microliter reverse transcriptase was then added and the samples incubated at $37^{\circ} \mathrm{C}$ for $1 \mathrm{~h}$. At the end of this incubation, the temperature was raised to $95^{\circ} \mathrm{C}$ for $5 \mathrm{~min}$. After chilling the tubes on ice, the samples were briefly centrifuged and the cDNA amplified by PCR using the M3 specific primers. The PCR was performed essentially as suggested by the manufacturers with minor modifications: $94^{\circ} \mathrm{C}$ for $45 \mathrm{~s}, 60^{\circ} \mathrm{C}$ for $1 \mathrm{~min}$, and $72^{\circ} \mathrm{C}$ for $2 \mathrm{~min}(38$ cycles). The last cycle was followed by a $10 \mathrm{~min}$ extension at $72^{\circ} \mathrm{C}$. The PCR products were analyzed by electrophoresis on $1.5 \%$ agarose gel. Rat or guinea pig brain cDNAs prepared in the same conditions were used as controls.

\subsection{In-situ hybridization}

Fifteen Wistar rats $(240-250 \mathrm{~g})$ and 10 guinea pigs (250-300 g) were used. The animals were deeply anesthetized with sodium pentobarbital (rats: $60 \mathrm{mg} / \mathrm{kg}$; guinea pigs: $90 \mathrm{mg} / \mathrm{kg}$ ) and fixed intra-aortically with ice-cold $1 \%$ paraformaldehyde in $0.1 \mathrm{M}$ sodium phosphate buffer, $\mathrm{pH}$ 7.4. After the perfusion, the brainstems and the cochleas were rapidly removed, dissected and postfixed in the same fixative for $1 \mathrm{~h}$ at $4^{\circ} \mathrm{C}$. The otic capsule and stria vascularis of the cochleas were carefully removed in the phosphate buffer. The tissues were then cryoprotected in the phosphate buffer containing $20 \%$ sucrose and cut on a Reichert-Jung cryostat at a $10-12 \mu \mathrm{m}$ thickness for the 
cochleas and at a $5 \mu \mathrm{m}$ thickness for the serial sections through the superior olivary complex. The sections were either used immediately for ISH or stored at $-70^{\circ} \mathrm{C}$ until use.

The oligonucleotides probes used in these experiments were purified by high performance liquid chromatography and their purity was confirmed using polyacrylamide gel electrophoresis. The M3 receptor antisense probe was 48 bases long. It was complementary to the sequence (4-51) of the coding region of the rat M3 receptor gene [20]. It was purchased from New England Nuclear (Boston, MA). The two ChAT oligonucleotide antisense probes were 30 and 36 bases long. They were complementary to bases 128-170 and 281-316 of the rat sequence [8], respectively. They were synthesized by Clontech (Palo Alto, CA).

The probes were labeled by a $3^{\prime}$-end-tailing procedure using terminal transferase. The labeling was initiated by incubating $1 \mathrm{nmol}$ digoxigenin (DIG, Boehringer-Mannheim, Germany) or $2.5 \mathrm{nmol}$ biotin-16-dUTP (Enzo Biochem Co., New York) for $30 \mathrm{~min}$ at $37^{\circ} \mathrm{C}$ with $10 \mathrm{pmol}$ (biotin labeling) or $100 \mathrm{pmol}$ (DIG labeling) oligonucleotide, $4 \mu 1$ of $5 \times$ terminal transferase labeling buffer $(1 \mathrm{M}$ potassium cacodylate, $0.125 \mathrm{M}$ Tris- $\mathrm{HCl}, 1.25 \mathrm{mg} / \mathrm{ml}$ bovine serum albumin, $\mathrm{pH} 6.6), 40 \mathrm{nmol} \mathrm{dATP}$ and $50 \mathrm{U}$ of terminal transferase (Boehringer-Mannheim, Germany). The final volume was adjusted to $20 \mu \mathrm{l}$ with double-distilled water. The reaction was stopped by adding $1 \mu \mathrm{l}$ of $0.5 \mathrm{M}$ EDTA, pH 7.2, then $0.5 \mu \mathrm{g}$ of tRNA (Sigma, St. Louis, MO). The probes were then precipitated with ethanol $/ 4 \mathrm{M}$ sodium chloride $(2.5: 0.1 ; \mathrm{v} / \mathrm{v})$ and kept at $-20^{\circ} \mathrm{C}$ until use. Just before use, the probes were centrifuged at $12000 \times g$ for $1 \mathrm{~h}$. The supernatant was removed, the pellet containing the probe was dried under vacuum and then resuspended in the hybridization buffer (50\% formamide, $4 \times$ sodium chloride/sodium citrate (SSC; SSC $1 \times=0.15 \mathrm{M}$ sodium chloride, $0.015 \mathrm{M}$ sodium citrate, $\mathrm{pH} 7), 1 \times$ Denhardt's solution $(0.02 \%$ Ficoll, $0.02 \%$ polyvinylpyrolidone and $0.02 \%$ bovine serum albumin), $0.5 \%$ L-laurylsarcosine, $10 \%$ dextran sulfate, 0.5 $\mathrm{mg} / \mathrm{ml}$ sheared single-stranded salmon sperm DNA).

The sections were soaked at room temperature in the pre-hybridization buffer $(4 \times \mathrm{SSC}$; SSC, $1 \times$ Denhart's solution, $0.5 \%$ L-laurylsarcosine) then dehydrated through $70 \%, 80 \%, 95 \%$ and absolute ethanol (3 min each). After air drying, the sections were incubated overnight at $42^{\circ} \mathrm{C}$ with $10 \mu \mathrm{l}$ of hybridization buffer containing $0.2 \mathrm{pmol}$ of biotinylated or DIG-labeled probe. After the hybridization, the sections were dipped in $4 \times \mathrm{SSC}$, rinsed in $1 \times \mathrm{SSC}(1$ $\mathrm{h}$ at room temperature and then $1 \mathrm{~h}$ at $40^{\circ} \mathrm{C}$ ) then in $0.1 \times \operatorname{SSC}\left(1 \mathrm{~h}\right.$ at $\left.40^{\circ} \mathrm{C}\right)$. They were then processed for biotin or DIG-detection, according to the probe used. Biotinylated hybrids were detected by the streptavidin-alkaline phosphatase method. Tissue sections were rinsed in buffer A (1 M NaCl, $0.1 \mathrm{M}$ Tris, $0.05 \mathrm{M} \mathrm{MgCl}_{2}, 0.5 \%$ Tween 20 , pH $7.5 ; 3 \times 20 \mathrm{~min}$ at room temperature) and incubated for $30 \mathrm{~min}$ at room temperature with streptavidin-alkaline phosphatase diluted 1:100 (Dako, Glostrup, Denmark). DIG-labeled hybrids were processed using an alkaline phosphatase-labeled anti-DIG antibody (Boehringer-Mannheim). The sections were then rinsed in buffer A $(3 \times 10 \mathrm{~min})$, in buffer B $(1 \mathrm{M} \mathrm{NaCl}, 0.1 \mathrm{M}$ Tris, 0.05 $\left.\mathrm{M} \mathrm{MgCl}_{2}, \mathrm{pH} 9.5 ; 2 \times 10 \mathrm{~min}\right)$, and in buffer $\mathrm{C}(0.5 \mathrm{M}$ $\mathrm{NaCl}, 0.1 \mathrm{M}$ Tris, $\left.0.05 \mathrm{M} \mathrm{MgCl}_{2}, \mathrm{pH} 9.5 ; 5 \mathrm{~min}\right)$. The alkaline phosphatase activity was revealed overnight in the dark with $0.33 \mathrm{mg} / \mathrm{ml}$ nitroblue tetrazolium and 0.16 $\mathrm{mg} / \mathrm{ml}$ 5-bromo-4-chloro-3-indolyl phosphate as chromogens (Bethesda Research Laboratories, Gaithersburg, MD). The reaction was stopped by rinsing the sections for $10 \mathrm{~min}$ in buffer $\mathrm{A}$, then for $10 \mathrm{~min}$ in double-distilled water. To clearly distinguish labeled neurons from the background, we did not counterstain sections before mounting. The sections were observed on a Reichert Polyvar microscope using Normarski optics.

To detect M3 mRNAs in the organ of Corti, which are badly preserved in cryostat sections, we hybridized in toto guinea pig cochleas. These cochleas were dissected as described above for cryosectioning, preincubated with 0.2 $\mathrm{M} \mathrm{HCl}\left(1 \mathrm{~h}, 60^{\circ} \mathrm{C} ;[19]\right)$ and incubated with the hybridization buffer $(1 \mathrm{~h})$ without the probe. They were then immersed in $30 \mu 1$ of hybridization buffer containing 0.6 pmol of the DIG-labeled M3 probe and hybridized overnight at $42^{\circ} \mathrm{C}$. The subsequent steps of the procedures were identical to those described just above for the cryostat sections. After the development of the alkaline phosphatase activity, the cochleas were cut on the cryostat and the $10-\mu \mathrm{m}$-thick sections were mounted and observed using Nomarski optics.

\section{Results}

\subsection{Reverse transcriptase-polymerase chain reaction}

Fig. 1 shows agarose gel electrophoresis of PCR products from rat cDNA. The cDNA corresponding to M3

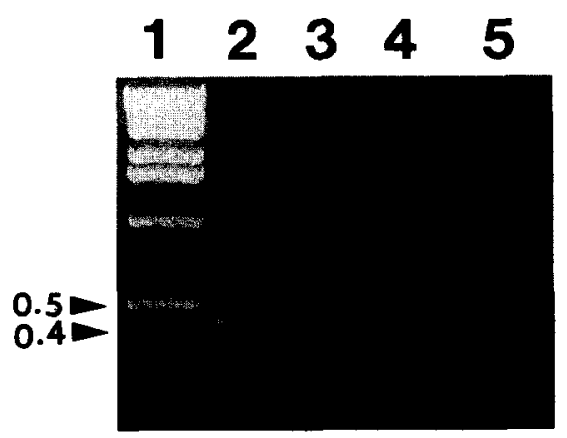

Fig. 1. Agarose gel electrophoresis of PCR products amplified from rat brain, organ of Corti and spiral ganglion with specific primers for M3 receptor sequence. Lane 1: 1-kb ladder standard; lane 2: brain; lane 3: spiral ganglion; lane 4: organ of Corti; lane 5: negative control without reverse transcriptase. The bands are labeled in units of $\mathrm{kb}$ pairs $(1-\mathrm{kb}$ DNA ladder standard; GIBCO-BRL). 
receptors were amplified from the brain samples of rats and guinea pigs (not shown). The band of interest had the molecular size of the expected PCR product, thus indicating the effectiveness of our PCR primers to drive the synthesis of the M3 sequence. The M3 band was likewise retrieved in the samples of spiral ganglion and organ of Corti from the two species. As negative controls, one of the primers or reverse transcriptase was omitted. In both cases, no cDNA was amplified. This rules out the possibility of a false-positive amplification from genomic DNA.

\subsection{In-situ hybridization}

Since no difference was observed between rat and guinea pig, we describe our results irrespective of the species, although most of the figures illustrate guinea pig data only.

\subsubsection{Control tissues}

No hybridization signal could be observed in the sections or cochleas except for an unspecific staining of the spiral limbus and, occasionally, the tectorial membrane of the organ of Corti. These control experiments were performed on alternate brainstem and spiral ganglion sections, and on cochleas hybridized in toto. They consisted in hybridizing the tissues with labeled sense probes (ChAT: synthesized by Clontech; M3: New England Nuclear, shown in Fig. 2A,D and 3A), with labeled antisense probes in the presence of an excess of unlabeled antisense probes, without labeled antisense probes or with an irrelevant
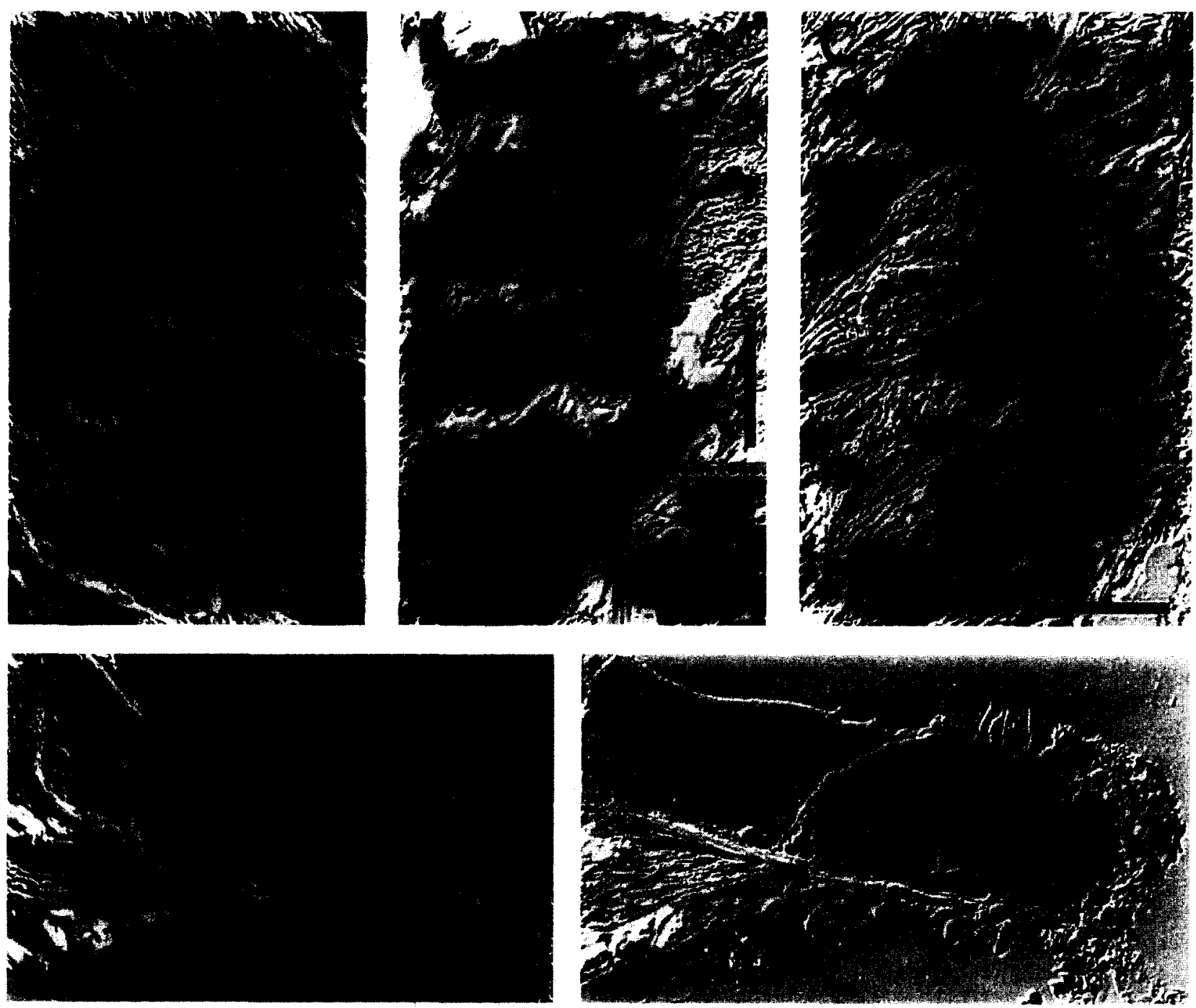

Fig. 2. Sections through the spiral ganglion of the guinea pig cochlea (A-C) and the organ of Corti (D,E). The sections have been hybridized with DIG-labeled M3 sense (A,D) and antisense (B,C,E) oligoprobes. No hybridization signal can be seen on the primary auditory neurons (A) or the inner (IHC) and outer (OHCs) hair cells in D. B (basal turn) and C (apical turn): nearly all the neurons express the M3 mRNAs. However, at both cochlear levels, some neurons, located peripherally in the ganglion, do not express the transeript (arrows). The thin arrows in B, C and the insert in B point on glial cells ensheathing the primary auditory neurons which do not express the transcript. E (from the second turn of the cochlea): both the OHCs and the IHC display an intense $\mathrm{M} 3$ signal. Scale bars: $50 \mu \mathrm{m}(\mathrm{A}-\mathrm{C}) ; 100 \mu \mathrm{m}(\mathrm{D}, \mathrm{E})$ 
30-base long oligonucleotide probe complementary to the calcitonin-specific region of the calcitonin/CGRP cDNA (New England Nuclear).

\subsubsection{Cochleas}

In both rat and guinea pig cochleas, the hybridization signal was uniformly distributed all along the entire spiral ganglion. The M3 receptor mRNAs were localized in nearly all large type I neurons, which were darkly stained (Fig. 2B,C). The preservation of the sections did not enable us to distinguish clearly the minor population of small type II neurons from that of large type I neurons.
This prevented an evaluation of the extent of the M3 mRNA expression in type II neurons. However, small neurons mainly located at the periphery of the ganglion, similarly to type II neurons, did not express M3 mRNAs (Fig. 2B,C). We also observed that satellite glial cells surrounding the large type I neurons were not labeled (Fig. $2 \mathrm{~B}, \mathrm{C}$ ), thus probably ruling out a glial participation in the cDNA amplification described above. This also precludes a participation of $\mathrm{M} 3$ receptors of glial origin in the muscarinic binding $[25,48]$ and the carbachol-evoked IP synthesis in the central region of the cochlea [4].

In the guinea pig organ of Corti from cochleas hy-
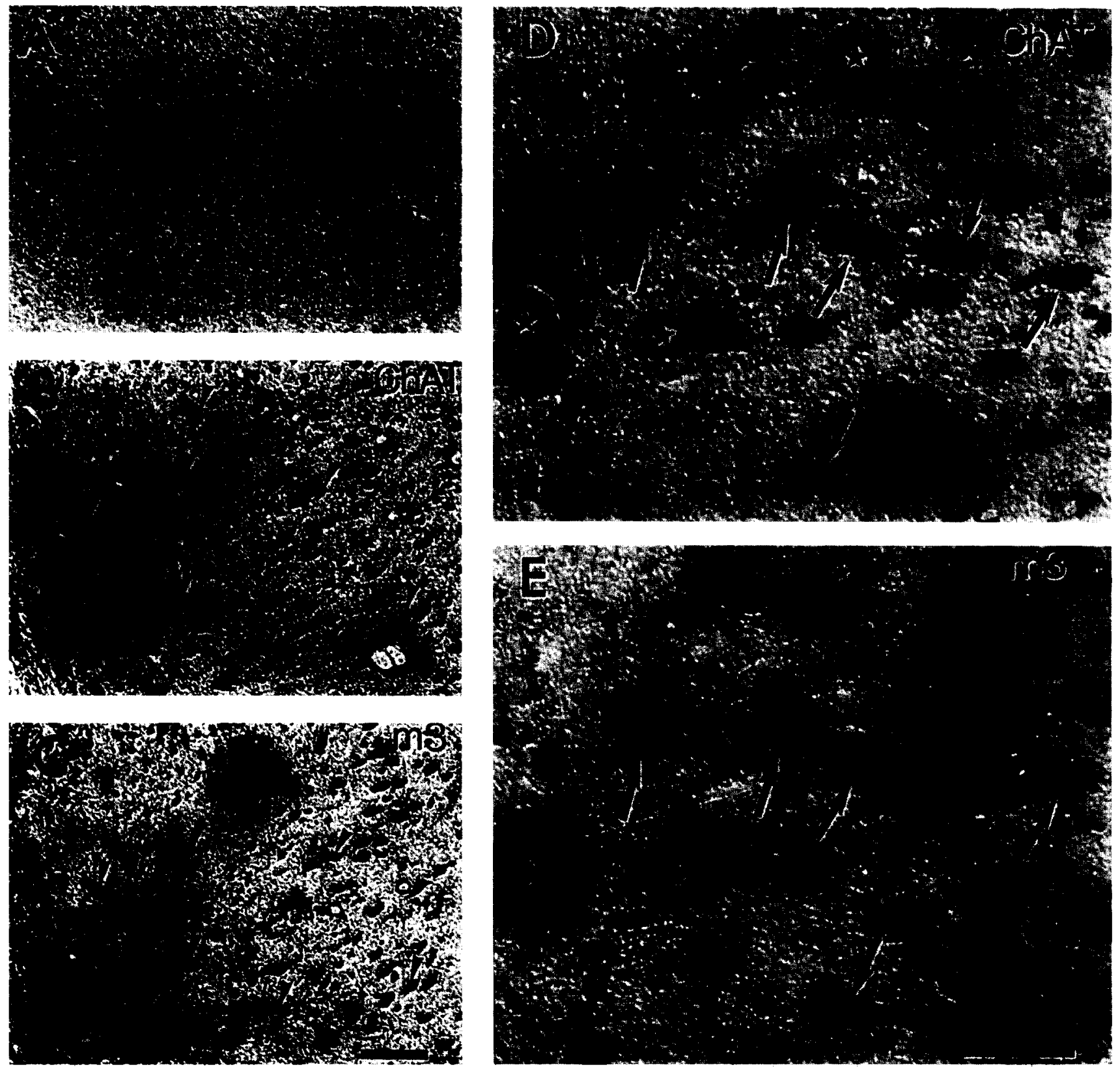

Fig. 3. Sections through the guinea pig $(\mathrm{A}-\mathrm{C})$ and rat $(\mathrm{D}, \mathrm{E})$ lateral superior olive. A: the section has been hybridized with a biotinylated $\mathrm{M} 3$ sense probe. Only background signal can be seen on this section. B,C and D,E: low and high magnifications, respectively, of serial sections hybridized with choline acetyltransferase (ChAT, B,D) or M3 (C,E) antisense biotinylated oligoprobes. The arrowheads in B,C and arrows in D,E point on neurons which express both ChAT and M3 mRNAs. Star: blood vessels. Scale bars: $250 \mu \mathrm{m}(\mathrm{A}-\mathrm{C}) ; 100 \mu \mathrm{m}(\mathrm{D}, \mathrm{E})$. 
bridized in toto, the $\mathrm{M} 3$ receptors hybrids were detected in the OHCs. All the OHCs from the lower cochlear turns were intensely labeled (Fig. 2E). Unlabeled OHCs could be seen in the upper turns and at the most apical level, no labeled OHCs could be found (not shown). An intense M3 mRNA expression was also detected in the IHCs all along the length of the organ of Corti (Fig. 2E).

\subsubsection{Superior olivary complex}

3.2.3.1. Lateral superior olive. In both the rat and guinea pig LSO, the M3 hybridization signal was observed in small spindle-shaped neurons (mean diameter: $15 \mu \mathrm{m}$ ) preferentially located in the medial limb. A similar observation was made in the serial sections hybridized with the antisense ChAT probes, in agreement with previous data dealing with ChAT mRNAs [38] and protein [37,46]. Indeed, when comparing the serial sections, we observed a one-to-one colocalization of the M3 and ChAT mRNAs in these small spindle-shaped neurons (Fig. 3).

3.2.3.2. Ventral nucleus of the trapezoid body. In the VNTB of both species, we also observed a one-to-one colocalization of the M3 and ChAT mRNAs in two populations of neurons (Fig. 4). One of these populations of neurons (Fig. 4) was formed by large multipolar neurons (mean diameter: $25 \mu \mathrm{m}$ ). These neurons were mainly located in the dorso-lateral part of the nucleus (Fig. 4A,B). The second population of colocalized neurons was mainly located in the ventro-medial part of the VNTB and was
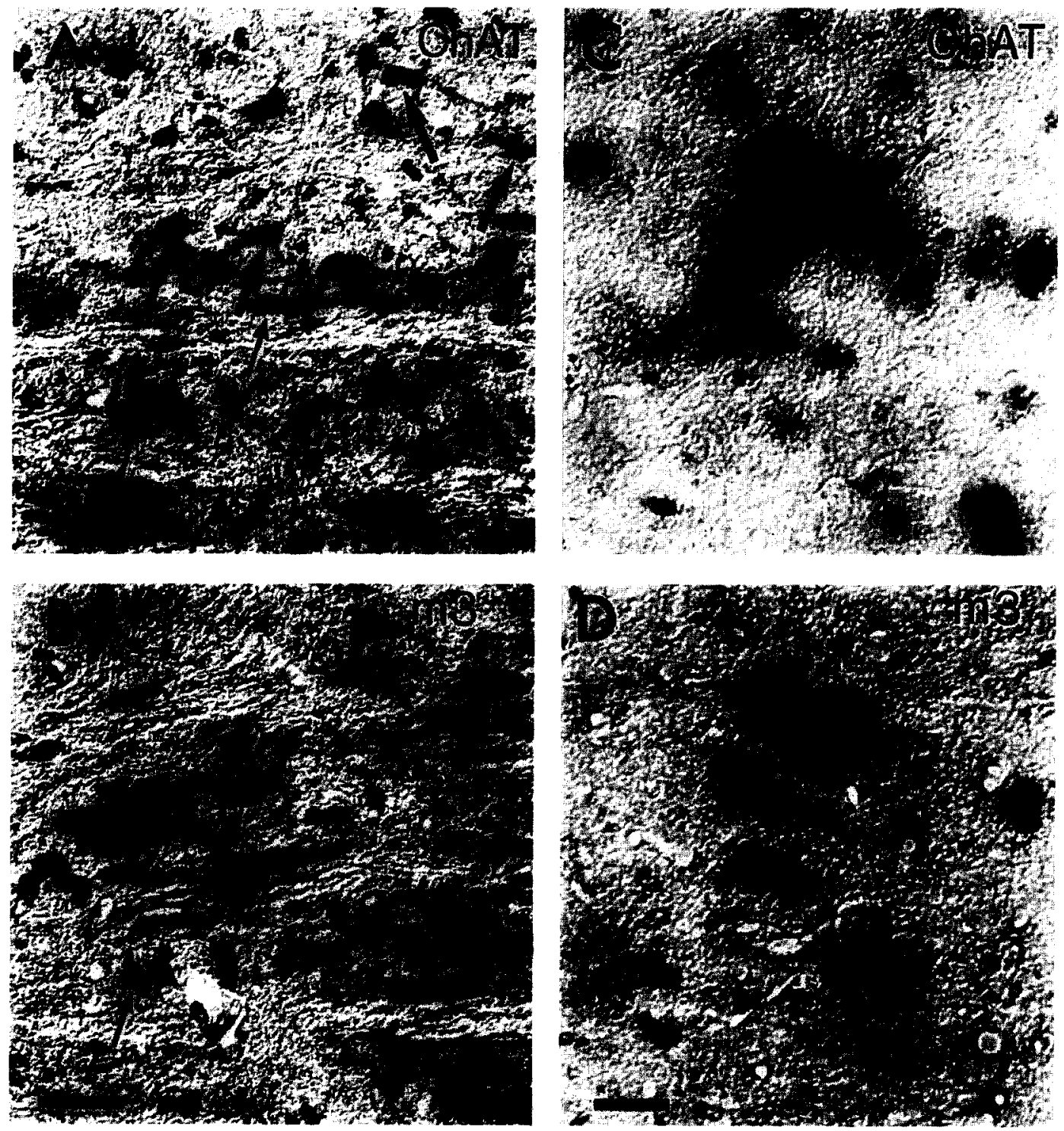

Fig. 4. Serial sections through the guinea pig $(A, B)$ and rat $(C, D)$ ventral nucleus of the trapezoid body (VNTB). The sections shown have been hybridized with DIG-labeled ChAT antisense $(A, C)$ or $M 3$ antisense $(B, D)$ probes. A,B: two populations of VNTB neurons expressing both ChAT and M3 mRNAs can be identified (thick arrows: large dorso-lateral neurons; thin arrows: small ventro-medial neurons). The top of A,B is oriented upward and the left side medialward. C,D: higher magnification of colocalized large-sized neurons. Scale bars: $100 \mu \mathrm{m}(\mathrm{A}, \mathrm{B}), 50 \mu \mathrm{m}(\mathrm{C}, \mathrm{D})$. 
formed by small neurons (mean diameter: $15 \mu \mathrm{m}$; Fig. $4 A, B)$. These small neurons probably corresponded to the small ChAT-like immunoreactive VNTB neurons which project to the cochlear nucleus [41].

\section{Discussion}

Our present data describing the amplification of M3 cDNAs from rat and guinea pig spiral ganglions and organs of Corti, and the localization of M3 mRNAs at the cellular level in these cochlear regions confirm at a gene level the pharmacological and electrophysiological data involving muscarinic receptors in cochlear physiology [17]. Our results are also consistent with the pharmacological data involving the M3 muscarinic receptor subtypes in the carbachol-induced IP formation in rat cochleas.

Previous experiments have associated the carbachol-induced IP formation with OHCs and medial efferent synapses [2,31], particularly since a peak of carbacholstimulated IP formation occurred at the time at which medial efferent fibers established synaptic contact with OHCs [2]. More recent experiments have suggested that the carbachol-stimulated IP formation also occurred in other places of the cochlea [4]. The expression of the M3 receptor cDNA in the spiral ganglion, the localization of its corresponding mRNA in primary auditory neurons, OHCs and IHCs, and in ChAT mRNA-containing neurons of the LSO and VNTB therefore suggest that the previously described muscarinic receptor-stimulated IP formation in the cochlea $[2,21,31,32]$ takes place in several loci (postsynaptic, presynaptic or 'non-synaptic').

\subsection{Postsynaptic expression of $M 3$ receptors in hair cells}

The M3 mRNAs presence in the OHCs agrees with the whole body of data (reviewed in [17]) associating acetylcholine with the medial efferent synapses with the OHCs. Particularly, it fits with the ability of acetylcholine to induce atropine-sensitive calcium mobilization [11] and outward currents $[11,15,26]$ in isolated OHCs. These outward currents were furthermore suppressed by 4-diphenylacetoxy- $N$-methyl piperidine methiodide (4-DAMP), a M3 antagonist $[15,26]$. Due to the calcium mobilizing ability of the IP-linked M3 receptors, one can thus speculate that this muscarinic cholinoceptor type is involved in the calciumdependent motile behavior of isolated OHCs $[13,40]$. This motile behavior observed in vitro may be involved in the suppressive effects of the olivocochlear efferent activation on distortion product otoacoustic emissions in vivo. Accordingly, it has been reported that muscarinic receptors may be involved in these suppressive effects [28], albeit they are primarily mediated by nicotinic receptors $[28,42]$.

The detection of M3 mRNAs in the IHCs was unexpected since it was widely agreed that, in the adult cochlea, IHCs lack efferent synapses (see [36]). However, whatever the species studied was, immature IHCs have been reported to be transiently contacted synapticaly by efferent fibers during the maturation of the cochlea, some days before the monitoring of the first cochlear responses $[29,35,43]$. In addition, transient efferent synapses have also been described on adult IHCs the days following an excitotoxic destruction of the radial afferent dendrites [34]. It has not yet been reported whether adult or immature IHCs that are transiently contacted by efferent terminals express functional M3 receptors. If this could be demonstrated, this would suggest that adult IHCs retain their potential to express M3 mRNAs, and maybe M3 receptors, in response to certain physiological conditions. This fits with preliminary results according to which acetylcholine blocks the ATP-induced $\mathrm{Ca}^{2+}$ mobilization in IHCs which have been isolated and maintained in culture conditions [50]. Such a line of reasoning could also apply for the newly described $\alpha 9$-subunit of nicotinic receptor which is also expressed by rat IHCs [14].

\section{2. $M 3$ receptors in type I neurons}

The M3 cDNA expression by spiral ganglion samples and particularly the M3 mRNA expression by type I neurons fit with a postsynaptic expression of $\mathrm{M} 3$ receptors on peripheral processes in the inner spiral bundle, just beneath the IHCs. These peripheral (dendritic) processes are contacted en passant by ChAT-like immunoreactive lateral efferents [16]. Acetylcholine has been shown to have a facilitatory effect on the subsynaptic afferent spontaneous or glutamate-evoked spiking activity [18]. This cholinergic facilitation occurred within several seconds, a latency which is consistent with the activation of metabotropic receptors such as the M3 receptor. However, no pharmacology has been done yet to ascribe this cholinergic effect to a given cholinergic receptor subtype.

Our ISH results also suggest that M3 receptors would be expressed presynapticaly by the axonal processes of type I neurons in the cochlear nucleus. This would fit with the description of muscarinic binding sites $[25,48]$ and carbachol-stimulated IP synthesis [4] in the central region of the cochlea, including the cochlear nerve. This would also fit with the fact that the axonal processes of type I neurons project on the same targets as axonic collaterals of cholinergic efferent neurons $[5,9,49]$ and/or axons of the recently described small moderately ChAT-like immunoreactive VNTB neurons [41].

\subsection{Presynaptic expression of $M 3$ receptors at lateral and medial cholinergic medial efferent synapses?}

We have also localized M3 receptor mRNAs in ChAT mRNAs-expressing neurons of the LSO and VNTB. Previous data based on retrograde tracing techniques combined with neurotransmitter labeling techniques have shown that the cochlea is innervated by LSO neurons and large VNTB neurons which strongly express a ChAT-like immuno- 
staining $[1,46]$. ChAT-like immunostained neurons of the LSO belong to the lateral efferent innervation while the large neurons of the VNTB belong to the medial efferent innervation. The small ChAT-like immunoreactive neurons in the VNTB form an additional neuronal population which innervates the cochlear nucleus [41]. It can thus be considered from our present observations of M3/ChAT mRNA colocalization that LSO neurons and large VNTB neurons belong to the lateral and medial efferent innervations to the cochlea, respectively, and that the small VNTB neurons belong to the cochlear nucleus innervation. Whether these M3 receptors correspond to possible postsynaptic receptors on the efferent neurons is still an open question since no cholinergic innervation of the LSO and the VNTB has been described yet. Indeed, the available data concerning neurotransmitters used by innervations ending in the LSO or the VNTB rather deal with amino acids, either inhibitory or excitatory (see [23]). It is thus conceivable that M3 receptors are expressed presynapticaly by the axonic terminals of these neurons. Concerning the medial efferent innervation, such a presynaptic expression of M3 receptors would agree with the recent report of a partial but significant decrease of the carbachol-stimulated IP formation in the rat cochlea after a section at the floor of the IVth ventricle of the contralateral component of the medial efferent innervation [4].

Available data in other nervous tissues or organs suggest an involvement of $\mathrm{M} 3$ autoreceptors in a down-regulation of the acetylcholine release [10,44,51]. In addition to such an inhibition of acetylcholine release, a regulation of the release of coexisting transmitters and/or of transmitters of surrounding lateral and medial efferent synapses may also be speculated. Lateral efferents may use at least five other neurotransmitters than acetylcholine (GABA, dopamine, enkephalins, dynorphins and CGRP) and medial efferents at least two others (GABA. CGRP), which all could coexist within the same neurons (see [17]). It has been reported that the release of dopamine in the striatum [27,30] and met-enkephalin in the superior colliculus [24] are stimulated by muscarinic receptors, while that of GABA in the diencephalon is blocked [45]. It is thus tempting to speculate similar modulatory functions in cochlear efferent terminals.

In conclusion, according to our data, muscarinic receptors of the M3 subtype can be expressed on the presynaptic and postsynaptic sides of efferent synapses of the organ of Corti, and presumably non-synapticaly in the IHCs. This suggests that the acetylcholine-induced IP turnover and its subsequent calcium mobilization play key roles in the metabolism of hair cells, primary auditory neurons and efferent terminals.

\section{Acknowledgements}

The authors wish to thank Profs. Rémy Pujol and Jochen Schacht and Drs. Marc Lenoir and Jean-Luc Puel for their comments on the manuscript, Nicole Renard for technical assistance and Pierre Sibleyras for photographic works. This work was supported by a research grant (3AM028) from the 'Convention CNAMTS-INSERM'.

\section{References}

[1] Abou-Madi, L., Pontarotti, P., Tramu, G., Cupo, A. and Eybalin, M. Coexistence of putative neuroactive substances in the lateral olivocochlear neurones of rat and guinea pig. Hearing Res., 30 (1987) $135-146$.

[2] Bartolami, S., Guiramand, J., Lenoir, M., Pujol, R. and Récasens, M. Carbachol-induced inositol phosphate formation during rat cochlea development. Hearing Res., 47, (1990) 229-234.

[3] Bartolami, S., Planche, M. and Pujol, R., Characterization of muscarinic binding sites in the adult and developing rat cochleas. Neurochem. Int., 23 (1993) 419-425.

[4] Bartolami, S., Ripoll, C.. Planche, M. and Pujol, R., Localization of functional muscarinic receptors in the rat cochlea: evidence for efferent presynaptic autoreceptors. Brain Res., 626 (1993) 200-209.

[5] Benson, T.E. and Brown, M.C., Synapses formed by olivocochlear axon branches in the mouse cochlear nucleus. J. Comp. Neurol., 295 (1990) $52-70$.

[6] Bonner, T.I., Buckley, N.J., Young, A.C. and Brann, M.R., Identification of a family of muscarinic receptor genes. Science, 237 (1987) $527-532$.

[7] Bonner, T.I., The molecular basis of muscarinic receptor diversity Trends Neurosci.. 12 (1989) 148-151.

[8] Brice, A., Berrard, B., Raynaud, S., Ansieau, T., Weber, M.J. and Mallet, J., Complete sequence of a cDNA encoding an active rat acetyltransferase: a tool to investigate the plasticity of cholinergic phenotype expression. J. Neurosci., 23 (1989) 266-273.

[9] Brown, M.C.. Pierce, S. and Berglund, A.M., Cochlear-nucleus branches of thick (medial) olivocochlear fibers in the mouse: a cochleotopic projection. J. Comp. Neurol., 303 (1991) 300-315.

[10] De Boer, P., Westerink, B.C.H., Rollema, H.. Zaagsma, J. and Horn, A.S., An M3-like muscarinic receptor regulates the in vivo release of acetylcholine in rat striatum. Eur. J. Pharmacol., 179 (1990) 167172.

[11] Doi, T. and Ohmori, H., Acetylcholine increases intracellular $\mathrm{Ca}^{2+}$ concentration and hyperpolarizes the guinea pig outer hair cell. Hearing Res., 67 (1993) 179-188.

[12] Drescher, D.G., Upadhyay. S., Wilcox, E. and Fex, J., Analysis of muscarinic receptors subtypes in the mouse cochlea by means of the polymerase chain reaction. J. Neurochem., 59 (1992) 765-767.

[13] Dulon, D., Zajic, G. and Schacht, J., Increasing intracellular free calcium induces circumferential contractions in isolated cochlear outer hair cells. J. Neurosci., 10 (1990) 1388-1397.

[14] Elgoyhen, A.B., Johnson, D.S., Boulter, J., Vetter, D.W. and Heinemann. S., $\alpha$ 9: an acetylcholine receptor with novel pharmacological properties expressed in rat cochlear hair cells. Cell, 79 (1994) $705-715$

[15] Erostegui, C., Norris, C.H. and Bobbin, R.P., In vitro pharmacologic characterization of a cholinergic receptor on outer hair cells. Hearing Res., 74 (1994) 135-147.

[16] Eybalin, M. and Pujol, R., Choline acetyltransferase (ChAT) immunoelectron microscopy distinguishes at least three types of efferent synapses in the organ of Corti. Exp. Brain Res., 65 (1987) 261-270.

[17] Eybalin, M., Neurotransmitters and neuromodulators of the mammalian cochlea. Physiol. Rev., 73 (1993) 309-373.

[18] Felix, D. and Ehrenberger, K., The efferent modulation of mammalian inner hair cell afferents. Hearing Res., 64 (1992) 1-5.

[19] Ghandour, M.S. and Skoff, R.P., Double-labeling in situ hybridization analysis of mRNAs for carbonic anhydrase II and myelin basic 
protein: expression in developing cultured glial cells. Glia, 4 (1991) $1-10$.

[20] Gocayne, J., Robertson, D.A., Fitzgerald, M.G., Chung, F.Z., Kerlavage, A.R., Lentes, K.U., Lai, J., Wang, C.D., Fraser, C.M. and Venter, J.C., Primary structure of rat cardiac $\beta 2$-adrenergic and muscarinic cholinergic receptors obtained by automated DNA sequence analysis: further evidence for a multigene family. Proc. Natl. Acad. Sci. USA, 84 (1987) 8296-8300.

[21] Guiramand, J., Mayat, E., Bartolami, S., Lenoir, M., Rumigny, J.-F., Pujol, R, and Récasens, M., A M3 muscarinic receptor coupled to inositol phosphate formation in the rat cochlea? Biochem. Pharmacol., 39 (1990) 1913-1919.

[22] Hulme, E.C., Birdsall, N.J.M. and Buckley, N.J., Muscarinic receptors subtypes. Annu. Rev. Pharmacol. Toxicol., 30 (1990) 633-673.

[23] Hunter, C., Doi, K. and Wenthold, R.J., Neurotransmission in the auditory system. Otolaryngol. Clin. N. Am., 25 (1992) 1027-1051.

[24] Illing, R.B., Nikolarakis, K.E., Wichmann, T., Spatz, W.B. and Starke, K., Release of met-enkephalin and its modulation through acetylcholine receptors in the rabbit superior colliculus. Exp. Brain Res., 82 (1990) 663-666.

[25] James, W.M., Cheatham, M.A. and Klein, W.L., Muscarinic acetylcholine receptor binding in the guinea pig cochlea. Hearing Res., 9 (1983) 113-121.

[26] Kakehata, S., Nakagawa, T., Takasaka, T. and Akaike, N., Cellular mechanism of acetylcholine-induced response in dissociated outer hair cells of guinea pig cochlea. J. Physiol., 463 (1993) 224-227.

[27] Kemel, M.-L., Gauchy, C., Desban, M., Krebs, M.O. and Glowinski, J., Control of dopamine release by acetylcholine and dynorphin in the striosomal and matrix compartments of the cat caudate nucleus. Neurochem. Int., 20 Suppl. (1992) 111S-114S

[28] Kujawa, S.G., Glattke, T.J., Fallon, M. and Bobbin, R.P., A nicotinic-like receptor mediates suppression of distorsion product otoacoustic emissions by contralateral sound. Hearing Res., 74 (1994) 122-134.

[29] Lenoir, M., Shnerson, A. and Pujol, R., Cochlear receptor development in the rat with emphasis on synaptogenesis. Anat. Embryol., 160 (1980) 253-262.

[30] Marchi, M., Volpe, G., Augliera, A., Codignola, A., Lunnardi, G. and Raiteri, M., Cholinergic modulation of dopamine release in corpus striatum and substantia nigra of the rat. Neurochem. Int., 20 Suppl. (1992) 271S-274S

[31] Niedzielski, A., Ono, T. and Schacht, J., Cholinergic regulation of the phosphoinositide second messenger system in the guinea pig organ of Corti. Hearing Res., 59 (1992) 250-254.

[32] Ogawa, K. and Schacht, J., Receptor-mediated release of inositol phosphates in the cochlear and vestibular sensory epithelia of the rat. Hearing Res., 69 (1993) 207-214.

[33] Plinkert, P.K., Zenner, H.-P. and Heilbronn, E., A nicotinic acetylcholine receptor-like alpha-bungarotoxin-binding site on outer hair cells. Hearing Res., 53 (1991) 123-130.

[34] Puel, J.-L., Safieddine, S., Gervais d'Aldin, C., Eybalin, M. and Pujol, R., Synaptic regeneration and functional recovery after excitotoxic injury in the guinea pig cochlea. CR Acad. Sci. Paris Sciences de la Vie / Life sciences, 318 (1995) 67-75.

[35] Pujol, R., Carlier, E. and Devigne, C., Different patterns of cochlear innervation during the development in the kittens. J. Comp. Neurol., 117 (1978) 529-536.
[36] Pujol, R. and Lenoir, M., The four types of synapses in the organ of Corti. In R.A. Altschuler, R.P. Bobbin and D.W. Hoffman (Ed.), Neurobiology of Hearing: the Cochlea, Raven Press, New York, 1986, pp. 161-172.

[37] Safieddine, S. and Eybalin, M., Triple immunofluorescence evidence for the coexistence of acetylcholine, enkephalins and calcitonin gene-related peptide within efferent (olivocochlear) neurons of rats and guinea-pigs. Eur. J. Neurosci., 4 (1992) 981-992.

[38] Safieddine, S. and Eybalin, M., Coexistence of efferent neurotransmitters. Immunocytochemical and in situ hybridization studies. First Conference on The Molecular Biology of Hearing and Deafness, La Jolla, CA, 1992, p. 107

[39] Safieddine, S. and Eybalin, M., Expression of neurotransmitter receptors mRNAs in rat and guinea pig auditory system. Assoc. Res. Otolaryngol. Abstr., 17 (1994) 59.

[40] Schacht, J. and Zenner, H.-P., Evidence that phosphoinositides mediate motility in cochlear outer hair cells. Hearing Res., 31 (1987) $155-160$.

[4I] Sherriff, F.E. and Henderson, Z., Cholinergic neurons in the ventral trapezoid nucleus project to the cochlear nuclei in the rat. Neuroscience, 58 (1994) 627-633.

[42] Siegel, J.H. and Kim, D.O., Efferent control of cochlear mechanics? Olivocochlear bundle stimulation affects cochlear biochemical nonlinearity. Hear. Res., 6 (1982) 171-182.

[43] Simmons, D.D., Manson-Gieseke, L., Hendrix, T.W. and McCarter, S., Reconstructions of efferent fibers in the postnatal hamster cochlea. Hearing Res., 49 (1990) 127-140.

[44] Soejima, O., Katsuragi, T. and Furukawa, T., Opposite modulation by muscarinic-(M1) and muscarinic-(M3) receptors of acetylcholine release from guinea pig ileum as measured directly. Eur. J. Pharmacol., 249 (1994) 1-6.

[45] Sugita, S., Uchimura, N., Jiang, Z.G. and North, R.A., Distinct muscarinic receptors inhibit release of GABA and excitatory amino acids in mammalian brain. Proc. Natl. Acad. Sci. USA, 88 (1991) 2608-2611.

[46] Vetter, D.E., Adams, J.C. and Mugnaini, E., Chemically distinct rat olivocochlear neurons. Synapse, 7 (1991) 21-43.

[47] Warr, W.B., Organization of olivocochlear efferent systems in mammals. In D.B. Webster, A.N. Popper and R.R. Fay (Ed.), The Anatomy of Mammalian Auditory Pathways. Vol l. The Mammalian A uditory Pathway: Neuroanatomy, Springer, Berlin/Heidelberg/New York, 1992, pp. 410-448.

[48] Whipple, M.R. and Drescher, D.G., Muscarinic receptors in the cochlear nucleus and auditory nerve of the guinea pig. J. Neurochem., 43 (1984) 192-198.

[49] Winter, I.M., Robertson, D. and Cole, K.S., Descending projections from auditory brainstem nuclei to the cochlea and cochlear nucleus of the guinea pig. J. Comp. Neurol., 280 (1989) 143-157.

[50] Yamashita, T., Amano, H., Ohtani, M., Harada, N. and Kumazawa, T., Calcium kinetics in cochlear inner hair cells of the guinea pig. Inner Ear Biol. Abstr., 28 (1991) 1.

[51] Yokotani, K., Okuma, Y., Nakamura, K. and Osumi, Y., Release of endogenous acetylcholine from a vascularly perfused rat stomach in vitro: inhibition by M3 muscarinic autoreceptors and alpha 2 adrenoceptors. J. Pharmacol. Exp. Ther., 266 (1993) 1190-1195. 